\title{
Influence of crystal growth conditions and carbothermal treatment on activator charge state in Ti:sapphire
}

\author{
S.V.Nizhankovskiy, N.S.Sidelnikova, V.V.Baranov \\ Institute for Single Crystals, STC "Institute for Single Crystals", \\ National Academy of Sciences of Ukraine, \\ 60 Nauky Ave., 61178 Kharkiv, Ukraine
}

Received July 25, 2017

\begin{abstract}
Presented are the results of comparative studies of the influence of carbothermal treatment of the raw material $\left(\mathrm{Al}_{2} \mathrm{O}_{3}\right.$ and $\mathrm{TiO}_{2}$ powders $)$ and reducing properties of the growth medium on the charge state of titanium ions in $\mathrm{Al}_{2} \mathrm{O}_{3}: \mathrm{Ti}$ crystals. It is shown that carbothermal treatment at temperatures of $1700-1800^{\circ} \mathrm{C}$ makes it possible to additionally decrease the relative content of titanium in the charge state $\mathrm{Ti}^{4+}$ by $2.5-3$ times.
\end{abstract}

Keywords: $\mathrm{Al}_{2} \mathrm{O}_{3}, \mathrm{TiO}_{2}$, carbothermal treatment.

Приведены результаты сравнительных исследований влияния восстановительных свойств среды выращивания и карботермической обработки шихты на зарядовое состояние ионов титана в кристаллах $\mathrm{Al}_{2} \mathrm{O}_{3}: \mathrm{Ti}$. Показано, что предварительная карботермическая обработка шихты при температурах $1700-1800^{\circ} \mathrm{C}$ позволяет дополнительно понизить в кристаллах содержание активатора в зарядовом состоянии $\mathrm{Ti}^{4+}$ в 3-4 раза.

Вплив умов вирощування та карботермічної обробки на зарядовий стан активатора у кристалах Ті:сапфіру. С.В.Нижанківський, Н.С.Сидельникова, В.В.Баранов.

Наведено результати порівняльних досліджень впливу відновлювальних властивостей середовища вирощування і карботермічної обробки шихти на зарядовий стан іонів титану у кристалах $\mathrm{Al}_{2} \mathrm{O}_{3}: \mathrm{Ti}$. Показано, що попередня карботермічна обробка шихти при температурах $1700-1800^{\circ} \mathrm{C}$ дозволяє додатково знизити у кристалах вміст активатора у зарядовому стані $\mathrm{Ti}^{4+}$ у $3-4$ рази.

\section{Introduction}

Laser efficiency of Ti:sapphire essentially depends on the value of optical loss at laser generation wavelengths in $(650-1100 \mathrm{~nm})$ region. As established in [1-4], Ti:sapphire has a wide absorption band with a maximum at $\sim 820 \mathrm{~nm}$ caused by the presence of the complex centers $\mathrm{Ti}^{3+}-\mathrm{Ti}^{4+}$ in the crystal. The generally accepted criterion of laser efficiency for this crystal is the value of FOM (figure of merit), i.e. the ratio between the values of optical absorption in the pumping region and of absorption at the generation maximum $(\sim 800 \mathrm{~nm})$. The intensity of parasitic absorption is defined by the concentration of the pairs $\mathrm{Ti}^{3+}-\mathrm{Ti}^{4+}$ which depends on the total content of titanium and its relative content in the charge state $\mathrm{Ti}^{4+}$. In its turn, the latter value depends on the partial pressure of oxygen in the technological crystal growth medium, thermal treatment and impurity composition.

The most widespread method for diminution of $\mathrm{Ti}^{4+}$ concentration is reducing annealing of the as-grown crystals which permits to raise the value of FOM up to 200250 and higher for weakly activated crystals with the concentration of titanium not exceeding 0.02-0.05 wt.\%. However, 
with the rise of the size of the crystal elements such a method becomes inefficient, since the required annealing duration increases as the square of the linear size of the element, and is accompanied with essential technological difficulties. Moreover, the increase of the activator concentration in the crystals considerably lowers the value of FOM. For small (up to 5-10 $\mathrm{mm}$ ) crystals with the concentration of titanium not lower than $0.07-0.15$ wt. $\%$, the value of FOM normally achieved by means of the annealing is $\approx 100-150$.

In the described method the reduction degree for titanium ions $\left(\mathrm{Ti}^{4+} \rightarrow \mathrm{Ti}^{3+}\right)$ is defined by the equilibrium constant of the oxidation-reduction reaction [4]:

$$
3 \mathrm{Ti}_{\mathrm{AI}}^{3+}+\frac{3}{4} \mathrm{O}_{2}(\text { gas }) \leftrightarrow 3 \mathrm{Ti}_{\mathrm{Al}}^{4+}+\mathrm{V}_{\mathrm{AI}}^{3-}+\frac{3}{2} \mathrm{O}_{0},
$$

which depends on the partial pressure of oxygen above the crystal and the concentration of anionic vacancies in the crystal [5]:

$$
\mathrm{K}_{\mathrm{ox}, \mathrm{V}}^{\mathrm{Ti}}=\frac{\left[\mathrm{Ti}_{\mathrm{A}}^{4+}\right]^{3}}{\left.\left[\mathrm{Ti}_{\mathrm{A}}^{3}\right]^{3}\right]^{3}}\left[\mathrm{~V}_{\mathrm{Al}}^{3-}\right] \mathrm{P}_{\mathrm{O}_{2}^{-3 / 4}}^{-}
$$

where [ $\left.\mathrm{Ti}_{\mathrm{A}}^{3+}\right]$ and [ $\left.\mathrm{Ti}_{\mathrm{A}}^{4}\right]$ is the concentration of $\mathrm{Ti}$ ions in the charge state $3^{+}$and $4^{+}$, respectively; $\left[\mathrm{V}_{\mathrm{Al}}^{3-}\right]$, the concentration of anionic vacancies; $\mathrm{P}_{\mathrm{O}_{2}}$, the partial pressure of oxygen in the growth medium. As follows from (2), the reduction degree for titanium ions $\mathrm{Ti}^{4+} \rightarrow \mathrm{Ti}^{3+}$ increases with the rise of the concentration of anionic vacancies and diminution of the partial pressure of oxygen. At the same time, as established earlier [6], a considerable increase of the concentration of anionic vacancies in inactivated sapphire crystals can be achieved not only due to reduction of the partial pressure of oxygen in the vapor phase of $\mathrm{Al}_{2} \mathrm{O}_{3}$, but also by means of carbothermal reduction (CTR) of the raw material. In the latter case carbon additive is introduced in the form of fine-dispersed powder of graphite (soot, etc.) or aluminium carbide $\left(\mathrm{Al}_{4} \mathrm{C}_{3}\right)$. Thereat, the concentration of anionic vacancies in the crystals considerably rises (up to $10^{18} \mathrm{~cm}^{-3}$ ), that can be estimated from the intensity of the optical absorption bands for $F$ and $F^{+}$-centers. It may be expected that CTR will promote more intense $\mathrm{Ti}^{4+} \rightarrow \mathrm{Ti}^{3+}$ reduction and allow to decrease the relative concentration of $\mathrm{Ti}^{4+}$ in $\mathrm{Al}_{2} \mathrm{O}_{3}: \mathrm{Ti}$ crystals.
Reported in [7] are the results on the growth of carbon-doped Ti:sapphire crystals by the Kyropoulos method which speak for this assumption. However, the presence of carbon at the crystal growth stage may considerably raise gas formation in the melt and lead to the formation of optical defects. In the developed approach CTR is used at the preliminary stage of the initial material treatment which must be optimized for the obtaining of the crystals with high optical quality and low absorption in the range of laser generation wavelengths.

The present work was aimed at comparative studies of the influence of the reducing properties of the growth medium and CTR on the content of the activator in the charge state $\mathrm{Ti}^{4+}$ and optical absorption in Ti:sapphire.

\section{Experimental}

Sapphire crystals with $\approx 7-8 \cdot 10^{-4}$ wt. $\%$ content of residual titanium additive and Ti:sapphire crystals containing $\approx 0.06$ wt. $\%$ of titanium with the dimensions 100$175 \times 100-175 \times 40 \mathrm{~mm}^{3}$ were grown from molybdenum crucibles in a furnace with carbon graphite thermal insulation [8] in low-pressure $\left(13-40 \mathrm{~Pa}, \mathrm{P}_{\mathrm{H}_{2}} / P_{\mathrm{CO}} \approx 0.01-0.04\right) \mathrm{CO}+$ $\mathrm{H}_{2}$ medium and in $\mathrm{Ar}$ atmosphere $\left(1.1 \cdot 10^{5} \mathrm{~Pa}-1.3 \cdot 10^{5} \mathrm{~Pa}\right)$, at the partial pressure of the reducing component $P_{\mathrm{CO}} / \mathrm{P}_{\mathrm{H}_{2}}$ 130-400 $\mathrm{Pa}, \mathrm{P}_{\mathrm{H}_{2}} / \mathrm{P}_{\mathrm{O}_{2}} \approx 0.01-0.1$. The concentration of $\mathrm{CO}, \mathrm{H}_{2}$ in the crystal growth atmosphere was controlled by a gas chromatograph "Crystal 2000M".

The crystallization rate was 2$2.5 \mathrm{~mm} / \mathrm{h}$. In the capacity of raw material we used fragments of sapphire crystals and $\mathrm{TiO}_{2}$ powder of $\approx 10^{-3}$ wt. $\%$ purity. During the growth of some crystals there was used $\mathrm{Al}_{2} \mathrm{O}_{3}+\mathrm{TiO}_{2}$ raw material preliminarily reduced by thermal treatment in $\mathrm{Ar}+\mathrm{CO}+$ $\mathrm{H}_{2}$ atmosphere for $20 \mathrm{~h}$ at a temperature of $2000 \mathrm{~K}$. The growth of $\mathrm{Al}_{2} \mathrm{O}_{3}$ and $\mathrm{Al}_{2} \mathrm{O}_{3}: \mathrm{Ti}$ with CTR performed using $\approx 0.1-1 \mathrm{wt}$. $\%$ of fine-dispersed graphite or $\mathrm{Al}_{4} \mathrm{C}_{3}$. CTR was realized during $5 \mathrm{~h}$ in $\mathrm{Ar}$ atmosphere (1.1$1.3 \cdot 10^{5} \mathrm{~Pa}$ ) at a temperature of $2000 \mathrm{~K}$.

\section{Results and discussion}

The present study included thermodynamic analysis and comparison of the values of the pressure of partial oxygen $\left(\mathrm{P}_{\mathrm{O}_{2}}\right)$ in the vapor phase of Ti:sapphire under the 
real conditions of the growth of crystals with the corresponding values of the region of stability for different phases in the system $\mathrm{TiO}-\mathrm{TiO}_{2}$ (Fig. 1). The changes in the thermodynamic potential $\Delta G^{0}$ per $\mathrm{O}_{2}$ mole resulting from successive oxidation

$$
\begin{aligned}
& \mathrm{Ti} \rightarrow \mathrm{TiO} \rightarrow \mathrm{Ti}_{2} \mathrm{O}_{3} \rightarrow \mathrm{Ti}_{3} \mathrm{O}_{5} \rightarrow \\
& \rightarrow \mathrm{Ti}_{4} \mathrm{O}_{7} \rightarrow \mathrm{Ti}_{n} \mathrm{O}_{2 n-1} \rightarrow \mathrm{TiO}_{2}
\end{aligned}
$$

were calculated using the reference data [9-11]. The pressure of molecular oxygen $\left(P_{O_{2}}{ }^{s}\right)$ in the vapor phase of $\mathrm{Al}_{2} \mathrm{O}_{3}$ in the low-pressure $\mathrm{CO}+\mathrm{H}_{2}$ atmosphere and $\mathrm{Ar}+$ $\mathrm{CO}+\mathrm{H}_{2}$ atmosphere with a total pressure of $1.1 \cdot 10^{5} \mathrm{~Pa}$ was calculated according to the procedure described in detail in $[6,12]$. Under the said conditions, $P_{O_{2}}{ }^{s}$ above $\mathrm{Al}_{2} \mathrm{O}_{3}$ melt of non-stoichiometric composition is presented by the expression:

$$
P_{\mathrm{O}_{2}}^{\mathrm{s}} \sim\left(F_{1}+F_{2} \cdot P_{\mathrm{CO}}+F_{3} \cdot P_{\mathrm{H}_{2}}\right)^{-2 / 5},
$$

where $F_{1}, F_{2}, F_{3}$ are the functions of several parameters, including the temperature and the total pressure of the medium. For $P_{O_{2}}{ }^{s}$ calculations we used the reference data

$[9,13,14]$. If the concentration of titanium in Ti:sapphire is lower than 1 wt. $\%$, it should be assumed that the pressure of oxygen in the vapour phase of Ti:sapphire to a sufficient accuracy coincides with the one in the vapour phase of $\mathrm{Al}_{2} \mathrm{O}_{3}$.

As seen from the results presented in Fig. 1 , at the melting temperature of $\mathrm{Al}_{2} \mathrm{O}_{3}$ the region of stable existence of the phase $\mathrm{Ti}_{2} \mathrm{O}_{3}$ corresponds to the values of oxygen potential $R \cdot T \cdot \ln \left(P_{O_{2}}\right)<-410 \mathrm{~kJ} /$ mole, i.e. the partial pressure of molecular oxygen above the system $P_{O_{2}}<6 \cdot 10^{-5} \mathrm{~Pa}$. Shown in the figure is the region of calculated values $R \cdot T \cdot \ln \left(P_{O_{2}}{ }^{s}\right)$ limited by the real conditions of the growth of Ti:sapphire (the me$\operatorname{dium~} \mathrm{CO}+\mathrm{H}_{2}, P_{\mathrm{CO}}+P_{\mathrm{H}_{2}}=13 \mathrm{~Pa}, P_{\mathrm{H}_{2}} / P_{\mathrm{CO}}$ $=0.01$; the atmosphere $\mathrm{Ar}+\mathrm{CO}+\mathrm{H}_{2}, P_{\mathrm{CO}}$ $\left.+P_{\mathrm{H}_{2}}=400 \mathrm{~Pa}, P_{\mathrm{H}_{2}} / P_{\mathrm{CO}}=1\right)$. Under such conditions $\mathrm{Ti}_{3} \mathrm{O}_{5}$ (with the mixed charge state $\left.\mathrm{Ti}^{3+}, \mathrm{Ti}^{4+}\right)$ is a stable phase. The values of $P_{\mathrm{O}_{2}}{ }^{s}$ corresponding to the region of stable existence for the phase $\mathrm{Ti}_{2} \mathrm{O}_{3}$, can be obtained only at lower partial pressures of oxygen above $\mathrm{Al}_{2} \mathrm{O}_{3}$ melt, that is hardly realized technologically.

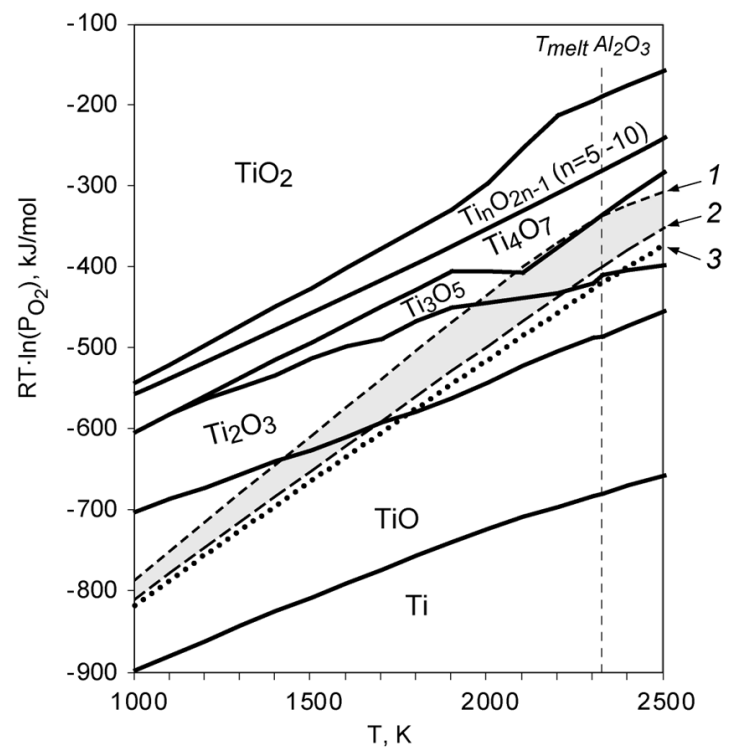

Fig. 1. Ellingham diagram for Ti-O system. Grey color denotes the region of real conditions during the growth of Ti:sapphire. 1 $P_{\mathrm{CO}}+P_{\mathrm{H}_{2}}=13 \mathrm{~Pa}, \quad P_{\mathrm{H}_{2}} / P_{\mathrm{CO}}=0.01 ; 2-$ $P_{\mathrm{Ar}+\mathrm{CO}+\mathrm{H}_{2}}=1 \cdot 1 \cdot 10^{5} \mathrm{~A}, P_{\mathrm{CO}}+P_{H_{2}}=400 \mathrm{~Pa}$, $P_{\mathrm{H}_{2}} / P_{\mathrm{CO}}=1 ; 3-P_{\mathrm{Ar}+\mathrm{CO}+\mathrm{H} 2}=1.1 \cdot 10^{5} \mathrm{~A}$, $P_{\mathrm{CO}}+P_{\mathrm{H}_{2}}=1600 \mathrm{~Pa}, P_{\mathrm{H}_{2}} / P_{\mathrm{CO}}=1$.

Thus, the performed estimations do not predict the possibility to provide an effective reduction of $\mathrm{Ti}^{4+}$ concentration during the growth of Ti:sapphire crystals. At the same time, these estimations show that at lower temperatures the region of stable existence for the phase $\mathrm{Ti}_{2} \mathrm{O}_{3}$ coincides with the region of calculated values of $R \cdot T \cdot \ln \left(P_{\mathrm{O} 2}\right)$ above Ti:sapphire. In other words, it should be expected that preliminary thermal treatment of the raw material, or post-growth annealing of the crystal under the said conditions will make it possible to decrease the concentration of $\mathrm{Ti}^{4+}$. To analyze the conditions of CTR it was necessary to consider possible reactions of $\mathrm{Al}_{2} \mathrm{O}_{3}$ and $\mathrm{TiO}_{2}$ with carbon. So, we studied the thermodynamic probability of some reactions with participation of $\mathrm{Al}_{2} \mathrm{O}_{3}$, carbon and $A$ carbide and oxycarbides within the temperature interval from 1000 to $2000 \mathrm{~K}$ at different compositions of CTR medium.

In particular, there were considered the reactions leading to the formation of condensed aluminum phase $\left(\mathrm{Al}_{\text {cond }}\right)$ and $\mathrm{CO}$, $\mathrm{CO}_{2}$ resulting in diminution of the content of oxygen in the raw material and in violation of the stoichiometry of $\mathrm{Al}_{2} \mathrm{O}_{3}$ crystal: 

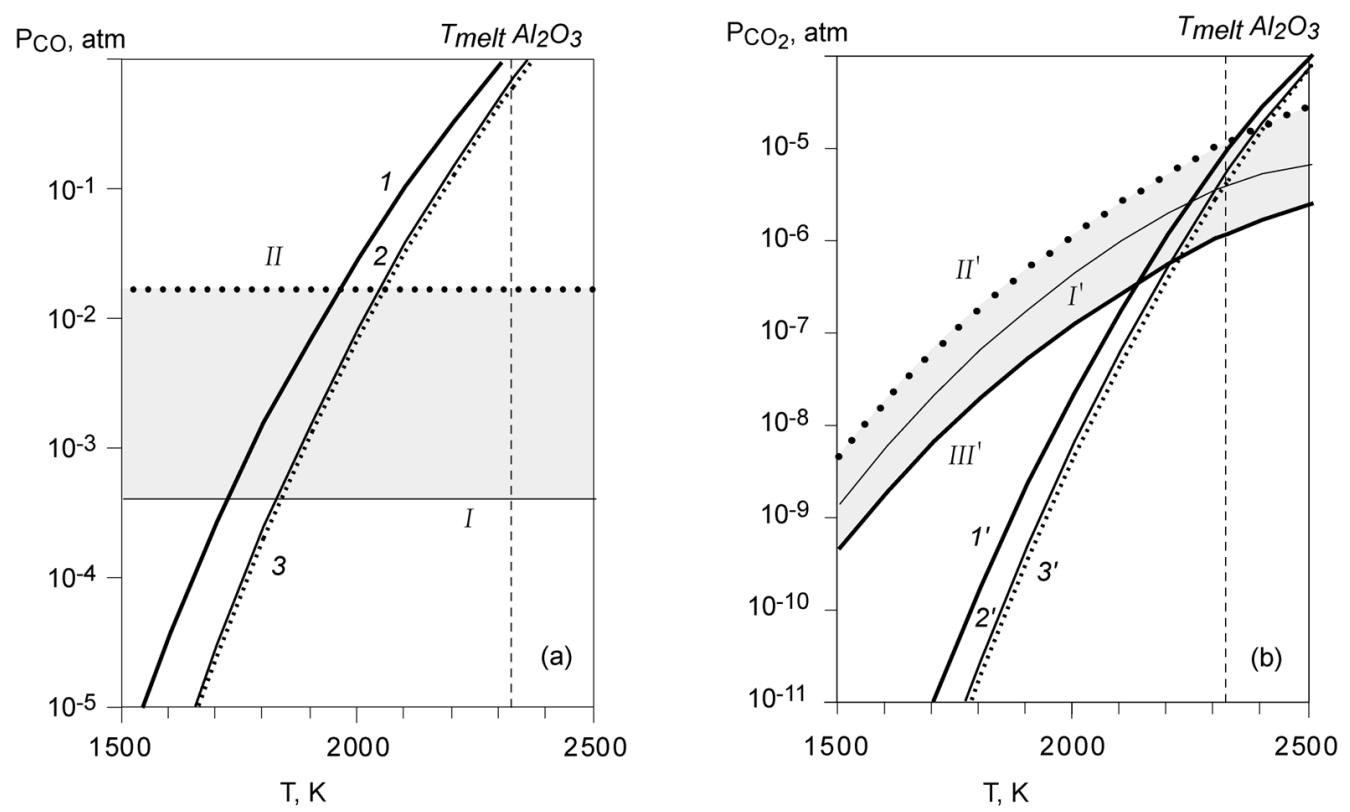

Fig. 2. Calculated temperature dependences of equilibrium pressure of gaseous products in reducing reactions with the formation of condensed $\mathrm{Al}$ phase: (a) $1,2,3-P_{\mathrm{CO}}$ for reactions $(4,6,8)$; I, II $-P_{\mathrm{CO}}$ in CTR medium; (b) - 1', 2', 3' $-P_{\mathrm{CO}_{2}}$ for reactions $(5,7,9) ; I^{\prime}, I I^{\prime}$ III' - calculated values of $P_{\mathrm{CO}_{2}}{ }^{s}$ above $\mathrm{Al}_{2} \mathrm{O}_{3}$ in the media $P_{\mathrm{CO}}+P_{\mathrm{H}_{2}}=40 \mathrm{~Pa}, P_{H_{2}} / P_{\mathrm{CO}}=0.01, \mathrm{Ar}+\mathrm{CO}+\mathrm{H}_{2}, P_{\mathrm{CO}}+$ $P_{H_{2}}=1600 \mathrm{~Pa}, P_{H_{2}} / P_{\mathrm{CO}}=1, P_{\mathrm{CO}}+P_{H_{2}}=40 \mathrm{~Pa}, P_{H_{2}} / P_{\mathrm{CO}}=1$, respectively.

$$
\begin{array}{r}
1 / 3 \mathrm{Al}_{2} \mathrm{O}_{3}+\mathrm{C} \leftrightarrow 2 / 3 \mathrm{Al}_{\text {cond. }}+\mathrm{CO} \uparrow, \quad \text { (4) } \\
2 / 3 \mathrm{Al}_{2} \mathrm{O}_{3}+\mathrm{C} \leftrightarrow 4 / 3 \mathrm{Al}_{\text {cond. }}+\mathrm{CO}_{2} \uparrow, \quad(5) \\
1 / 3 \mathrm{Al}_{2} \mathrm{O}_{3}+1 / 3 \mathrm{Al}_{4} \mathrm{C}_{3} \leftrightarrow 2 \mathrm{Al}_{\text {cond. }}+\mathrm{CO} \uparrow,(6) \\
2 / 3 \mathrm{Al}_{2} \mathrm{O}_{3}+1 / 3 \mathrm{Al}_{4} \mathrm{C}_{3} \leftrightarrow 8 /\left.3 \mathrm{Al}\right|_{\text {cond. }}+\mathrm{CO}_{2} \uparrow,(7) \\
1 / 4 \mathrm{Al}_{4} \mathrm{O}_{4} \mathrm{C}+1 / 4 \mathrm{Al}_{4} \mathrm{C}_{3} \leftrightarrow 2 \mathrm{Al}_{\text {cond. }}+\mathrm{CO} \uparrow, \quad(8) \\
1 / 2 \mathrm{Al}_{4} \mathrm{O}_{4} \mathrm{C}+1 / 6 \mathrm{Al}_{4} \mathrm{C}_{3} \leftrightarrow 8 / 3 \mathrm{Al} \text { cond. }
\end{array}
$$

The ones followed by the formation of $\mathrm{Al}$ carbide and oxycarbides and $\mathrm{CO}, \mathrm{CO}_{2}$ subsequently leading to reactions (6) $-(9)$ :

$$
\begin{gathered}
1 / 3 \mathrm{Al}_{2} \mathrm{O}_{3}+3 / 2 \mathrm{C} \leftrightarrow 1 / 6 \mathrm{Al}_{4} \mathrm{C}_{3}+\mathrm{CO} \uparrow, \text { (10) } \\
2 / 3 \mathrm{Al}_{2} \mathrm{O}_{3}+2 \mathrm{C} \leftrightarrow 1 / 3 \mathrm{Al}_{4} \mathrm{C}_{3}+\mathrm{CO}_{2} \uparrow, \quad \text { (11) } \\
1 / 2 \mathrm{Al}_{2} \mathrm{O}_{3}+3 / 2 \mathrm{C} \leftrightarrow 1 / 2 \mathrm{Al}_{2} \mathrm{OC}+\mathrm{CO}(12) \\
\mathrm{Al}_{2} \mathrm{O}_{3}+2 \mathrm{C} \leftrightarrow \mathrm{Al}_{2} \mathrm{OC}+\mathrm{CO}_{2} \uparrow, \\
\mathrm{Al}_{2} \mathrm{O}_{3}+3 / 2 \mathrm{C} \leftrightarrow 1 / 2 \mathrm{Al}_{4} \mathrm{O}_{4} \mathrm{C}+\mathrm{CO} \uparrow,
\end{gathered}
$$

$$
\begin{gathered}
\mathrm{Al}_{2} \mathrm{O}_{3}+2 \mathrm{C} \leftrightarrow \mathrm{Al}_{4} \mathrm{O}_{4} \mathrm{C}+\mathrm{CO}_{2} \uparrow, \\
1 / 4 \mathrm{Al}_{4} \mathrm{O}_{4} \mathrm{C}+3 / 2 \mathrm{C} \leftrightarrow 1 / 4 \mathrm{Al}_{4} \mathrm{C}_{3}+\mathrm{CO} \uparrow,(1 \\
1 / 2 \mathrm{Al}_{4} \mathrm{O}_{4} \mathrm{C}+2 \mathrm{C} \leftrightarrow 1 / 2 \mathrm{Al}_{4} \mathrm{C}_{3}+\mathrm{CO}_{2} \uparrow,(1 \\
\mathrm{Al}_{2} \mathrm{OC}+3 / 2 \mathrm{C} \leftrightarrow 1 / 2 \mathrm{Al}_{4} \mathrm{C}_{3}+\mathrm{CO} \uparrow, \\
2 \mathrm{Al}_{2} \mathrm{OC}+2 \mathrm{C} \leftrightarrow \mathrm{Al}_{4} \mathrm{C}_{3}+\mathrm{CO}_{2} \uparrow
\end{gathered}
$$

The reactions resulting in the formation of $\mathrm{Al}_{\text {cond }}$ with subsequent violation of $\mathrm{Al}_{2} \mathrm{O}_{3}$ stoichiometry (4)-(9) and then leading to $\mathrm{Ti}^{4+} \rightarrow \mathrm{Ti}^{3+}$ reduction according to the scheme:

$$
\left(\mathrm{V}_{\mathrm{O}^{+}}^{+}+2 e\right)+\mathrm{Ti}^{4+} \leftrightarrow\left(\mathrm{V}_{\mathrm{O}}^{++}+e\right)+\mathrm{Ti}^{3+}
$$

where $\left(\mathrm{V}_{\mathrm{O}^{+}}^{+}\right)+2 e$ is a neutral $F$-center; $\left(\mathrm{V}_{\mathrm{O}}^{++}\right)+e, F^{+}$-center.

The reactions resulting in the formation of gaseous products of $\mathrm{Al}_{2} \mathrm{O}_{3}$ dissociation:

$$
\mathrm{Al}_{2} \mathrm{O}_{3}+\mathrm{C} \leftrightarrow\left(\mathrm{Al}, \mathrm{AlO}, \mathrm{Al}_{2} \mathrm{O}\right) \uparrow+\left(\mathrm{CO}, \mathrm{CO}_{2}\right) \uparrow
$$

do not increase the degree of $\mathrm{Al}_{2} \mathrm{O}_{3}$ nonstoichiometry, they only raise the evapora- 

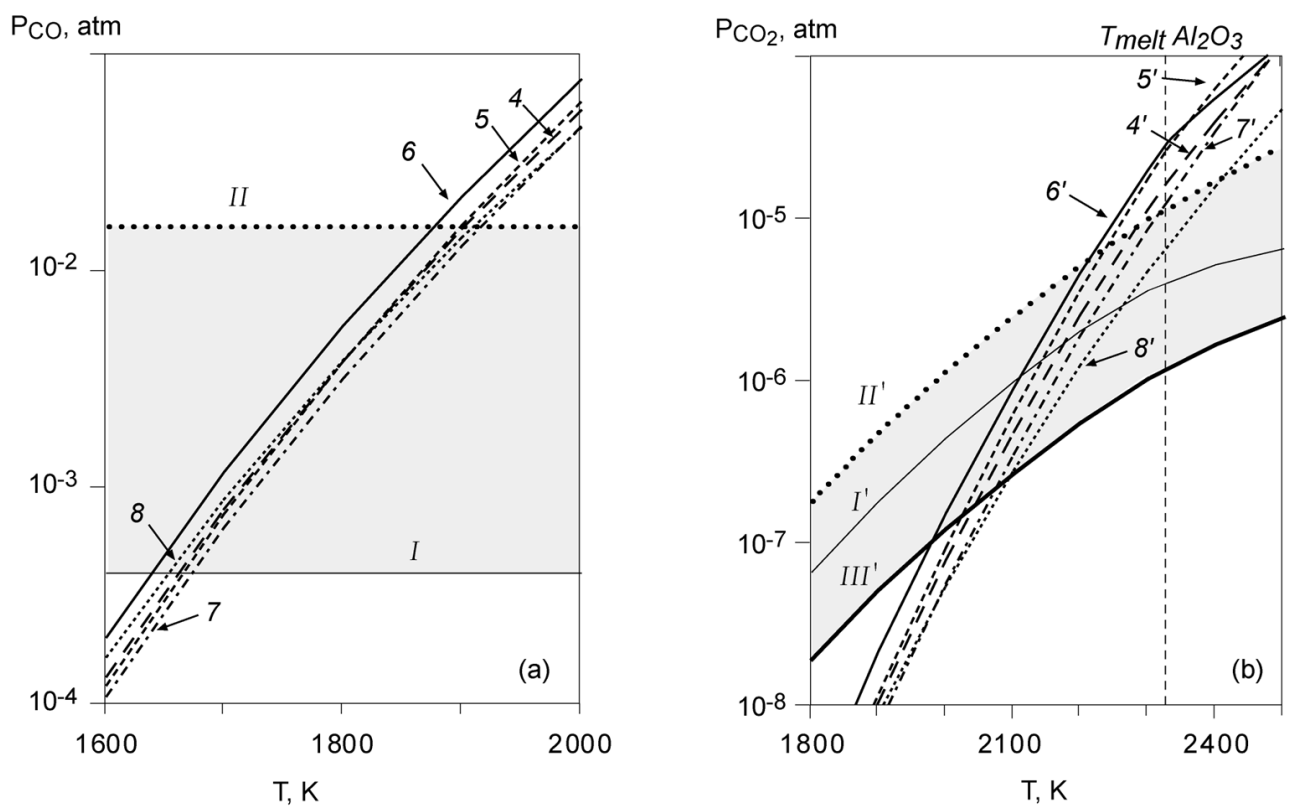

Fig. 3. Temperature dependences of equilibrium pressure of gaseous products in reducing reactions with the formation of Al carbide and oxycarbides. (a) (6) - (10) $-P_{\mathrm{CO}}$ for reactions (10), (12), (14), (16), (18); I, II $-P_{\mathrm{CO}}$ CTR medium; (b) (4') $-\left(\right.$ 8' $^{\prime}-P_{\mathrm{CO}_{2}}$ for reactions (11), (13), (15), (17),

(19); I', II' III' - calculated $P_{\mathrm{CO}_{2}}$ v values in the media $P_{\mathrm{CO}}+P_{H_{2}}=40 \mathrm{~Pa}, P_{H_{2}} / P_{\mathrm{CO}}=0.01, \mathrm{Ar}+\mathrm{CO}$ $+\mathrm{H}_{2}, P_{\mathrm{CO}}+P_{H_{2}}=1600 \mathrm{~Pa}, P_{H_{2}} / P_{\mathrm{CO}}=1, P_{\mathrm{CO}}+P_{H_{2}}=40 \mathrm{~Pa}, P_{H_{2}} / P_{\mathrm{CO}}=1$, respectively.

tion rate. Therefore, these reactions are excluded from further analysis.

The temperature dependences of equilibrium pressure for the gaseous products $\left(\mathrm{CO}, \mathrm{CO}_{2}\right)$ of the reducing reactions leading to the formation of $\mathrm{Al}_{\text {cond }}$ are presented in Fig. 2. Shown in Fig. 3 are the temperature dependences of the reactions resulting in the formation of $\mathrm{Al}$ carbide and oxycarbides. The values of equilibrium $\mathrm{CO}$ and $\mathrm{CO}_{2}$ pressure are determined from the known expressions for equilibrium constants of the reactions:

$$
\Delta G^{0}=R T \ln K,
$$

where $\Delta G^{0}$ is the change of the thermodynamic potential in the reaction realized under standard conditions; $R$, the gas constant; $K$, the equilibrium constant of the reaction defined by the ratio of the partial pressures of the reaction products and the reagents; for reactions (2)-(17) it corresponds to $P_{\mathrm{CO}}$ or $P_{\mathrm{CO}_{2}}$. The changes in the thermodynamic potential $\Delta G^{0}$ per 1 mole of $\mathrm{CO}, \mathrm{CO}_{2}$ were calculated using the reference data [13, 14] and the data from [15] for aluminium carbide and oxycarbides.

Shown in Fig. $2 \mathrm{a}$ and $3 \mathrm{a}$ are the regions of $P_{\mathrm{CO}}$ values in the CTR medium $\mathrm{CO}+\mathrm{H}_{2}$,
$P_{\mathrm{CO}}+P_{\mathrm{H}_{2}}=40 \mathrm{~Pa}$ (curve $\mathrm{I}$ ) and in the atmosphere $\mathrm{Ar}+\mathrm{CO}+\mathrm{H}_{2}=1600 \mathrm{~Pa}$ (curve II). Fig. $2 \mathrm{~b}$ and $3 \mathrm{~b}$ present the calculated $P_{\mathrm{CO} 2}{ }^{s}$ values in the gas phase above $\mathrm{Al}_{2} \mathrm{O}_{3}$ melt, in the CTR medium $\mathrm{CO}+\mathrm{H}_{2}, \quad P_{\mathrm{CO}}+P_{\mathrm{H} 2}=$ $40 \mathrm{~Pa}, P_{\mathrm{H} 2} / P_{\mathrm{CO}}=1$ (curve III') and in the atmosphere $\mathrm{Ar}+\mathrm{CO}+\mathrm{H}_{2}, \quad P_{\mathrm{CO}}+P_{\mathrm{H} 2}=$ $1600 \mathrm{~Pa}, P_{\mathrm{H} 2}+P_{\mathrm{CO}}=1$ (curve II'). Under such conditions $P_{\mathrm{CO} 2}$ s value essentially differs from the equilibrium value above graphite and is defined by the equilibrium condition of the reaction

$$
\mathrm{CO}+1 / 2 \mathrm{O}_{2} \leftrightarrow \mathrm{CO}_{2}
$$

above corundum obtained from the expression:

$$
P_{\mathrm{CO}_{2} \mathrm{~s}}=\left(P_{\mathrm{CO}_{2} \mathrm{~s}}\right) \cdot P_{\mathrm{CO}} \cdot K_{\mathrm{CO}_{2}}
$$

where $P_{\mathrm{CO}_{2}}$ is defined by dependence (3), $K_{\mathrm{CO}_{2}}$ is the constant of reaction (23). The value of $P_{\mathrm{CO}_{2}^{s}}$ was calculated using the reference data $[14,18,19]$.

As seen while comparing the regions of real composition of the CTR medium with the values of equilibrium pressure $P_{\mathrm{CO}}$ and $P_{\mathrm{CO}_{2}}$ for reactions (4)-(19), the considered 
Table 1. Calculated values of onset temperature for reactions (2)-(17) at different composition of the medium in crystallization chamber

\begin{tabular}{|c|c|c|c|c|c|c|}
\hline \multirow{2}{*}{$\begin{array}{l}\text { Number of } \\
\text { reaction } \\
\text { (denotation } \\
\text { of curve in } \\
\text { Fig. } 2,3 \text { ) }\end{array}$} & \multicolumn{2}{|c|}{ Composition of medium } & \multirow{2}{*}{$\begin{array}{l}\text { Number of } \\
\text { reaction } \\
\text { (denotation } \\
\text { of curve in } \\
\text { Fig. } 2,3 \text { ) }\end{array}$} & \multicolumn{3}{|c|}{ Composition of medium } \\
\hline & $P_{\mathrm{CO}}=40 \mathrm{~Pa}$ & $P_{\mathrm{CO}}=1600 \mathrm{~Pa}$ & & $\begin{array}{l}P_{\mathrm{CO}}+P_{\mathrm{H} 2}= \\
40 \mathrm{~Pa}= \\
P_{\mathrm{H} 2} / P_{\mathrm{CO}}=1\end{array}$ & $\begin{array}{c}P_{\mathrm{CO}}+P_{\mathrm{H} 2}= \\
40 \mathrm{~Pa} \\
P_{\mathrm{H} 2} / P_{\mathrm{CO}}=0.01\end{array}$ & $\begin{array}{l}P_{\mathrm{CO}}+P_{\mathrm{H} 2}= \\
1600 \mathrm{~Pa} \\
P_{\mathrm{H} 2} / P_{\mathrm{CO}}=1\end{array}$ \\
\hline $2(1)$ & 1723 & 1956 & $3\left(1^{\prime}\right)$ & 2135 & 2250 & 2342 \\
\hline $4(2)$ & 1826 & 2043 & $5\left(2^{\prime}\right)$ & 2202 & 2300 & 2390 \\
\hline $6(3)$ & 1837 & 2054 & $7\left(3^{\prime}\right)$ & 2225 & 2320 & 2405 \\
\hline $8(4)$ & 1662 & 1902 & $9\left(4^{\prime}\right)$ & 2043 & 2175 & 2282 \\
\hline $10(5)$ & 1665 & 1898 & $11\left(5^{\prime}\right)$ & 2023 & 2145 & 2236 \\
\hline $12(6)$ & 1638 & 1876 & $13\left(6^{\prime}\right)$ & 1980 & 2115 & 2212 \\
\hline $14(7)$ & 1673 & 1915 & $15\left(7^{\prime}\right)$ & 2074 & 2207 & 2313 \\
\hline $16(8)$ & 1654 & 1910 & $17\left(8^{\prime}\right)$ & 2095 & 2264 & 2408 \\
\hline
\end{tabular}

reactions are thermodynamically probable starting from temperatures lower than the melting point. The onset temperatures for the reactions leading to the formation of $\mathrm{CO}$ are lower than those for the reactions resulting in the formation of $\mathrm{CO}_{2}$. With the increase of $P_{\mathrm{CO}}$ in the crystal growth medium the reaction onset temperature rises, too. At the same time, the onset temperature for the reactions with $\mathrm{CO}_{2}$ formation also depends on the value of $P_{\mathrm{H}_{2}} / P_{\mathrm{CO}}$ ratio in the medium, that is bound up with dependences (3) and (24). The calculations of the reaction onset temperatures at different compositions of the medium in the crystallization chamber are presented in Table 1. As follows from the results shown in Fig. 2, 3 and Table 1, in the presence of carbon and $\mathrm{Al}_{4} \mathrm{C}_{3}$ in the raw material the reduction efficiency rises as $P_{C O}$ value in the crystallization chamber decreases. This can be successfully achieved at lower pressures of the medium. However, in this case it is necessary to take into account an essential increase of evaporation rate for the raw material and the melt according to reactions (21). Moreover, the calculations show that in the presence of carbon in the raw material, the reduction processes leading to the formation of condensed $\mathrm{Al}$ phase which give rise to violation of stoichiometry in $\mathrm{Al}_{2} \mathrm{O}_{3}$, start at temperatures higher than those for the reactions with the formation of $\mathrm{Al}$ carbide and oxycarbides. Therefore, one may expect that the presence of carbon and $\mathrm{Al}_{4} \mathrm{C}_{3}$ will exert equivalent action on the reduction process. Further it will be shown that, according to experimental studies, the intensities of the absorption bands bound up with the presence of $F$ - and $\mathrm{Ti}^{4+}$-centers in the optical spectra of $\mathrm{Al}_{2} \mathrm{O}_{3}: \mathrm{Ti}$ crystals grown with CTR do not acquire noticeable changes at introduction of graphite or $\mathrm{Al}_{4} \mathrm{C}_{3}$ in the raw material. The presence of carbon in the raw material also facilitates the reduction of titanium oxides with subsequent formation of lower oxide and gaseous products of $\mathrm{CO}, \mathrm{CO}_{2}$ according to the reactions:

$$
\begin{gathered}
4 \mathrm{TiO}_{2}+\mathrm{C}=\mathrm{Ti}_{4} \mathrm{O}_{7}+[\mathrm{CO}\} \uparrow, \\
8 \mathrm{TiO}_{2}+\mathrm{C}=2 \mathrm{Ti}_{4} \mathrm{O}_{7}+\left[\mathrm{CO}_{2}\right\} \uparrow, \\
3 \mathrm{Ti}_{4} \mathrm{O}_{7}+\mathrm{C}=4 \mathrm{Ti}_{3} \mathrm{O}_{5}+[\mathrm{CO}\} \uparrow, \\
6 \mathrm{Ti}_{4} \mathrm{O}_{7}+\mathrm{C}=8 \mathrm{Ti}_{3} \mathrm{O}_{5}+\left[\mathrm{CO}_{2}\right\} \uparrow, \\
2 \mathrm{Ti}_{3} \mathrm{O}_{5}+\mathrm{C}=3 \mathrm{Ti}_{2} \mathrm{O}_{3}+[\mathrm{CO}\} \uparrow, \\
4 \mathrm{Ti}_{3} \mathrm{O}_{5}+\mathrm{C}=6 \mathrm{Ti}_{2} \mathrm{O}_{3}+\left[\mathrm{CO}_{2}\right\} \uparrow, \\
\mathrm{Ti}_{2} \mathrm{O}_{3}+\mathrm{C}=2 \mathrm{TiO}+[\mathrm{CO}\} \uparrow, \\
2 \mathrm{Ti}_{2} \mathrm{O}_{3}+\mathrm{C}=4 \mathrm{TiO}+[\mathrm{CO}\} \uparrow .
\end{gathered}
$$

The temperature dependences of the equilibrium pressure of $\mathrm{CO}, \mathrm{CO}_{2}$ in these reactions are presented in Fig. 4. The calculations of the changes in the thermodynamic potential $\Delta G^{\mathrm{O}}$ per 1 mole of $\mathrm{CO}, \mathrm{CO}_{2}$ due to the reaction of successive reduction $\mathrm{TiO}_{2} \rightarrow \mathrm{Ti}_{n} \mathrm{O}_{2 n-1} \rightarrow \mathrm{Ti}_{4} \mathrm{O}_{7} \rightarrow \mathrm{Ti}_{3} \mathrm{O}_{5} \rightarrow \mathrm{Ti}_{2} \mathrm{O}_{3}$ $\rightarrow$ TiO were made using the reference data $[10,11,13]$. As well as in the case of reactions (4)-(19), the equilibrium pressure of 

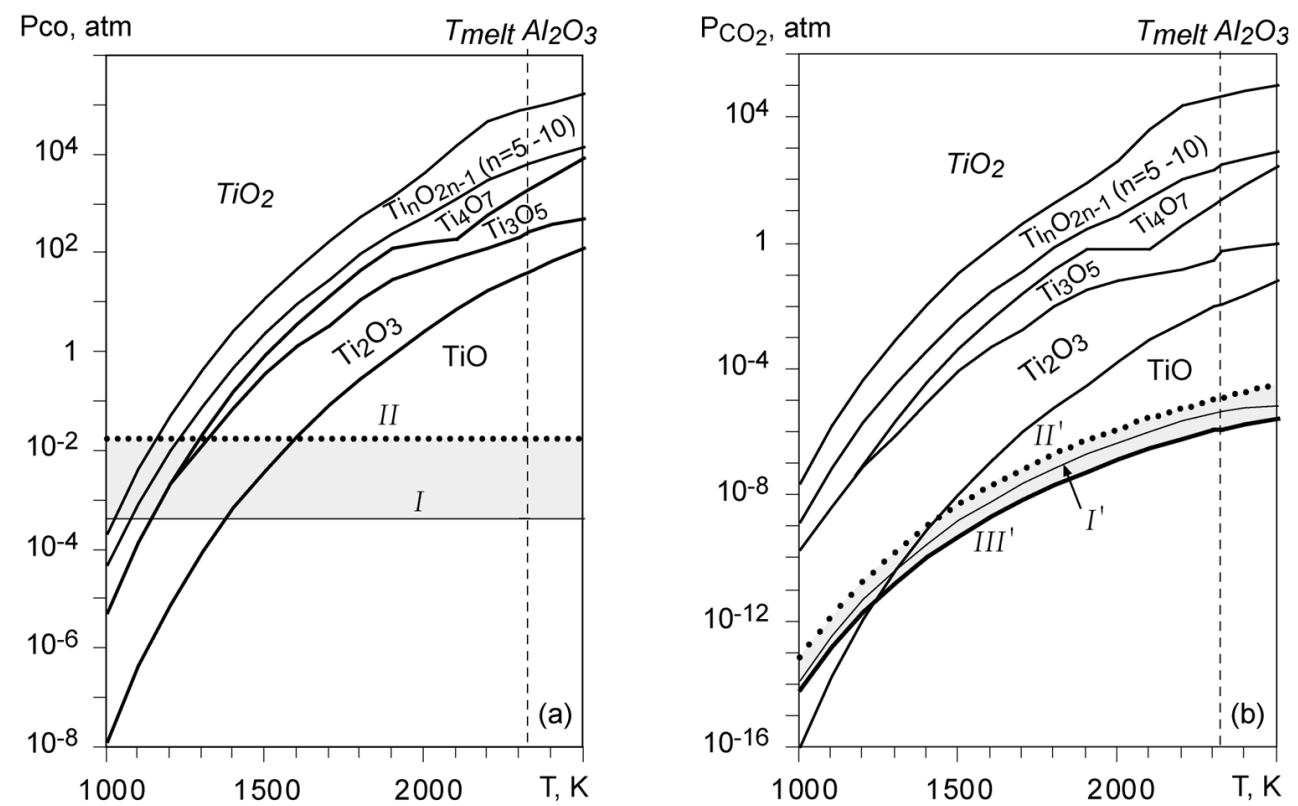

Fig. 4. Temperature dependences of equilibrium pressure of $\mathrm{CO}$ (a) and $\mathrm{CO}_{2}$ (b) at reduction of titanium oxides with/by carbon. I, II $-P_{\mathrm{CO}}$ in the growth medium; I', II' III' - calculated $P_{\mathrm{CO} 2}{ }^{s}$ qvalues in the medium $P_{\mathrm{CO}}+P_{\mathrm{H} 2}=40 \mathrm{~Pa}, P_{\mathrm{H} 2} / P_{\mathrm{CO}}=0.01, \mathrm{Ar}+\mathrm{CO}+\mathrm{H}_{2}, P_{\mathrm{CO}}+P_{\mathrm{H} 2}=1600 \mathrm{~Pa}$, $P_{\mathrm{H} 2} / P_{\mathrm{CO}}=1, P_{\mathrm{CO}}+P_{\mathrm{H} 2}=40 \mathrm{~Pa}, P_{\mathrm{H} 2} / P_{\mathrm{CO}}=1$, respectively.

$\mathrm{CO}$ and $\mathrm{CO}_{2}$ was determined from the expressions for the equilibrium constants of the reactions using relation (22). By analogy with Fig. 2, 3, shown in Fig. 4 are the regions of the real $P_{\mathrm{CO}}$ values and the calculated $P_{\mathrm{CO}_{2}}$ values in the gas phase above $\mathrm{Al}_{2} \mathrm{O}_{3}$ limited by the values characteristic of the process of Ti:sapphire growth in the low-pressure medium $\left(P_{\mathrm{CO}}+P_{\mathrm{H}_{2}}\right)=40 \mathrm{~Pa}$, $P_{\mathrm{H}_{2}} / P_{\mathrm{CO}}=1$ - curve III') and in the atmosphere $\mathrm{Ar}+\mathrm{CO}+\mathrm{H}_{2}, P_{\mathrm{CO}}+P_{\mathrm{H} 2}=1600 \mathrm{~Pa}$, $P_{\mathrm{H} 2} / P_{\mathrm{CO}}=1$ - curve II'). Likewise Fig. 1, the diagram presented in Fig. 4 characterizes the regions of stability for different phases in the system $\mathrm{TiO}-\mathrm{TiO}_{2}$, but in the presence of carbon and the gas phase $\mathrm{CO}$ or $\mathrm{CO}_{2}$.

Let us compare the real composition of the growth medium with the values of $P_{\mathrm{CO}}$ and $P_{\mathrm{CO} 2}$ equilibrium pressures for reactions $(25)-(32)$. One can see that within the whole considered interval of the reducing medium composition these reactions, as well as reactions (4)-(9), favour intense $\mathrm{Ti}^{4+} \rightarrow \mathrm{Ti}^{3+}$ reduction and diminution of the relative $\mathrm{Ti}^{4+}$ concentration.

The obtained thermodynamic estimations, in particular, the reaction onset temperature, as well as the experimental data for the growth of $\mathrm{Al}_{2} \mathrm{O}_{3}: \mathrm{C}$ crystals were used for the growth of $\mathrm{Al}_{2} \mathrm{O}_{3}: \mathrm{Ti}$ with CTR.
Fig. 5 presents the optical absorption spectra of the standard (nominally pure) crystals of sapphire containing $\approx 7 \cdot 10^{-4}$ wt $\%$ of residual titanium additive and of Ti:sapphire with $\approx 0.06$ wt $\%$ titanium content grown in $\mathrm{Ar}+\mathrm{CO}+\mathrm{H}_{2}$ atmosphere, $P_{\mathrm{CO}}+P_{\mathrm{H} 2} \sim 400 \mathrm{~Pa}$, $P_{\mathrm{H} 2} / P_{\mathrm{CO}}=\approx 0.1$, in $P_{\mathrm{CO}}+P_{\mathrm{H} 2} \approx 7 \mathrm{~Pa}$ atmosphere, as well as the spectra of $\mathrm{Al}_{2} \mathrm{O}_{3}$ and $\mathrm{Al}_{2} \mathrm{O}_{3}$ :Ti crystals with CTR.

As shown by investigations, the optical characteristics of such crystals essentially depend on the partial pressure of the reducing components $\left(P_{\mathrm{CO}}, P_{\mathrm{H} 2}\right)$ at all the stages of the crystallization process, as well as on the concentration of polyvalent titanium additive in the raw material. If the crystal growth conditions provide the transition of a considerable portion of titanium into the charge state $\mathrm{Ti}^{3+}$, then the absorption band of neutral $F$-centers $(\sim 205 \mathrm{~nm})$ is dominating in the UV-region. If the growth conditions do not provide such a transition, then the said spectral region contains the dominating broad non-elementary band at 200$250 \mathrm{~nm}$ bound up with the presence of titanium in the charge state $\mathrm{Ti}^{4+}$. As seen from Fig. 5, such a spectrum is characteristic of sapphire grown in a low-pressure medium (curve 2). At the same time, the absorption band of neutral $F$-centers prevails in the spectra of the nominally pure crystals grown in the atmosphere $\mathrm{Ar}+\mathrm{CO}+\mathrm{H}_{2}$ 

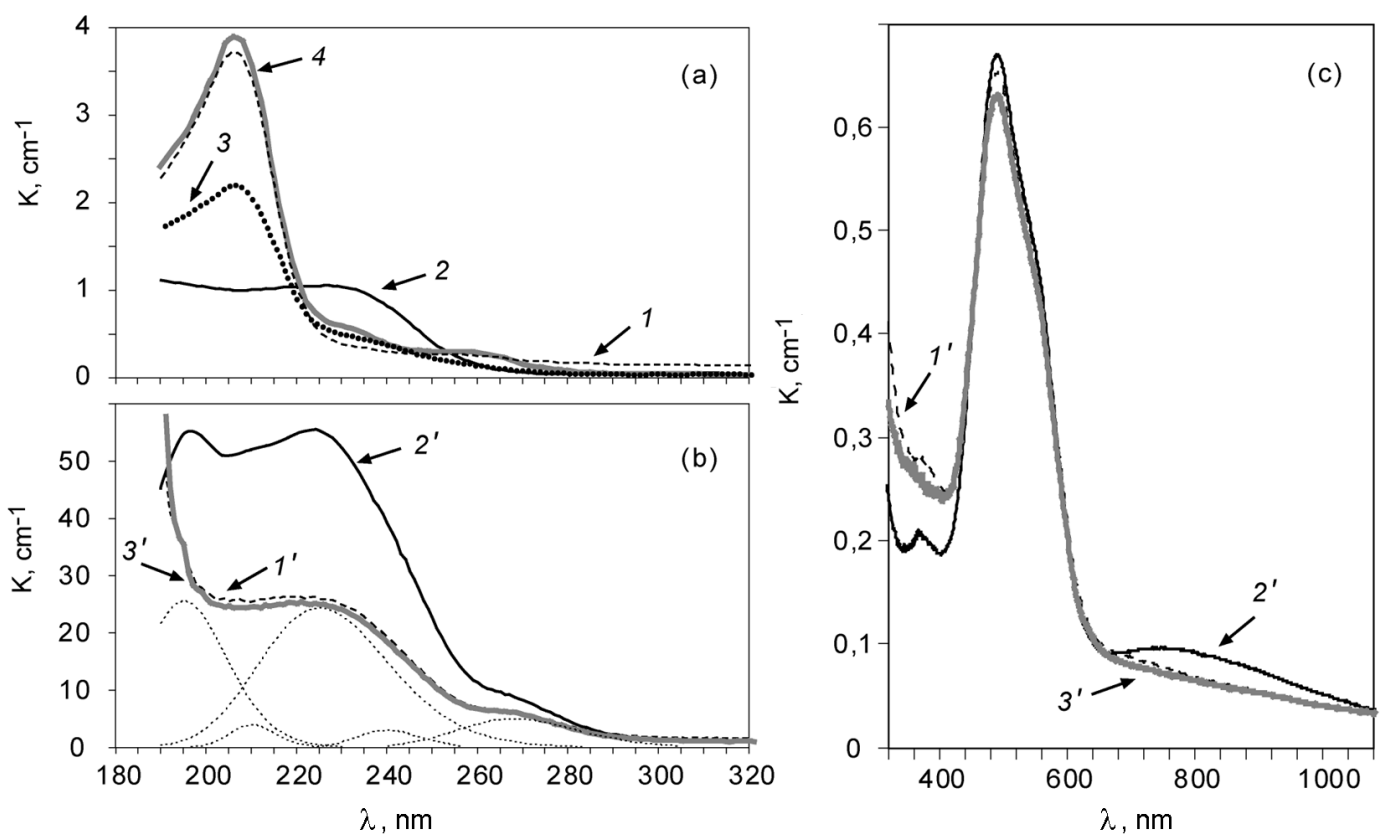

Fig. 5. Optical absorption spectra for sapphire with $\approx 7 \cdot 10^{-4} \mathrm{wt} \%$ residual titanium content (a) and Ti:sapphire containing $\approx 0.06 \mathrm{wt} \%$ of titanium $(\mathrm{b})$ grown in the media $\approx 0.1$ (1), (1') and $P_{\mathrm{CO}}+$ $P_{\mathrm{H} 2} \approx 7 \mathrm{~Pa},(2),(2 ')$, and the spectra for the crystals grown in the medium $P_{\mathrm{CO}}+P_{\mathrm{H} 2} \approx 7 \mathrm{~Pa}$ from the raw material containing $\approx 0.3 \mathrm{wt} \%$ of $C(3), \approx 1 \mathrm{wt} \%$ of $C\left(3^{\prime}\right)$ and $\approx 1 \mathrm{wt} \%$ of $\mathrm{Al}_{4} \mathrm{C}_{3}$ (4). In Fig.5(b) dotted lines show decomposition of the spectrum (3') into Gaussian components.

(curve 1), as well as in the ones of $\mathrm{Al}_{2} \mathrm{O}_{3}: \mathrm{C}$ crystals grown in a low-pressure medium (curve 3,4 ). In other words, the presence of additional inner source of reduction exerts the same influence on the process of titanium reduction as a considerable increase of the reduction potential of the crystal growth medium. It should be also noted that, in comparison with the nominally pure crystals, $\mathrm{Al}_{2} \mathrm{O}_{3}: \mathrm{C}$ crystals contain a considerably higher concentration of $F^{+}$-centers (the bands at $\sim 230$ and $\sim 260 \mathrm{~nm}$ ). It has been assumed that the formation of elevated concentration of $\mathrm{F}^{+}$-centers in such crystals is caused by substitution of trivalent Al cation by bivalent carbon ion, and by the formation of $F^{+}$-center as a compensator of $\mathrm{C}^{2+}$ charge [16, 17]. Along with the above-said widespread viewpoint, there exists an alternative assumption to the effect that carbon in $\mathrm{Al}_{2} \mathrm{O}_{3}: \mathrm{C}$ crystal is an anionic additive, and $\mathrm{F}^{+}$centers function as $\mathrm{C}^{4-}$ charge compensators in the $\mathrm{O}^{2-}$ position in $\mathrm{Al}_{2} \mathrm{O}_{3}$ lattice [18]. Irrespective of the mechanism of $\mathrm{F}^{+}$-center formation, the character of the spectra of $\mathrm{Al}_{2} \mathrm{O}_{3}: \mathrm{C}$ crystals (curves 3, 4 in Fig. 5) testifies that during the growth of these crystals $\mathrm{C}$ and $\mathrm{Al}_{4} \mathrm{C}_{3}$ are not consumed completely as a result of reactions (4)-(9) and (25)-(32): they are partially dissolved in the crystal and influence its optical characteristics.
In the UV-region the optical absorption spectrum of $\mathrm{Al}_{2} \mathrm{O}_{3}: \mathrm{Ti}$ crystal grown in the low-pressure medium (curve 2') contain the characteristic absorption band at 200$250 \mathrm{~nm}$ bound up with $\mathrm{Ti}^{4+}$. Its intensity is observed to essentially diminish with the rise of the reduction potential of the growth medium (curve 1'), as well as for $\mathrm{Al}_{2} \mathrm{O}_{3}: \mathrm{Ti}$ crystals with CTR (curve 3 '). The absorption in the band at $\sim 800 \mathrm{~nm}$ related to the presence of $\mathrm{Ti}^{3+}-\mathrm{Ti}^{4+}$ centers in the crystal also decreases (Fig. 5c).

Preliminary studies show that the same effect is also observed at introduction of $\mathrm{Al}_{4} \mathrm{C}_{3}$ into the raw material. The optical absorption spectra allowed to estimate the values of $\left[\mathrm{Ti}^{4+}\right] /\left\{\mathrm{Ti}^{3+}\right]$ in $\mathrm{Al}_{2} \mathrm{O}_{3}: \mathrm{Ti}$ crystals and in the ones with CTR (Table 2).

The concentration of $\mathrm{Ti}^{4+}$ was estimated from the intensity of the absorption band with a maximum at $225 \mathrm{~nm}$ bound up with the presence of $\mathrm{Ti}^{4+}$ according to the Smakula's formula:

$$
=0.87 \cdot 10^{17} \cdot n \cdot\left(2+n^{2}\right)^{-2} \cdot K_{\max } \cdot \Delta, \mathrm{cm}^{-3},
$$

where $K_{\max }$ is the absorption coefficient; $\Delta$, the peak width at the half-intensity; $n$, the refractive index at the wavelength corre- 
Table 2. Growth conditions for $\mathrm{Al}_{2} \mathrm{O}_{3}: \mathrm{Ti}$ and $\mathrm{Al}_{2} \mathrm{O}_{3}: \mathrm{Ti}$ crystals with $\mathrm{CTR}$ and $\left[\mathrm{Ti}^{4+}\right] /\left[\mathrm{Ti}^{3+}\right]$ ratio in these crystals

\begin{tabular}{|c|c|c|c|c|c|}
\hline $\begin{array}{l}\text { Number } \\
\text { of crystal }\end{array}$ & Crystal & $\begin{array}{l}\text { Composition and } \\
\text { conditions for raw } \\
\text { material preparation }\end{array}$ & $\begin{array}{l}\text { Composition of } \\
\text { crystal growth } \\
\text { medium }\end{array}$ & $\begin{array}{c}\text { Values of } R \cdot T \cdot \ln \left(P_{\mathrm{O} 2} s\right. \\
\text { (calculation of } P_{\mathrm{O} 2} \\
\text { from }(1) \text { at } \\
T=2327 \mathrm{~K}) \text { values }\end{array}$ & $\begin{array}{c}{\left[\mathrm{Ti}^{4+}\right] /\left[\mathrm{Ti}^{3+}\right]} \\
\text { values }\end{array}$ \\
\hline 1 & $\mathrm{Al}_{2} \mathrm{O}_{3}: \mathrm{Ti}$ & $\mathrm{Al}_{2} \mathrm{O}_{3}+\mathrm{TiO}_{2}$ & $\begin{array}{c}P_{\mathrm{CO}}+P_{\mathrm{H} 2} \approx 7 \mathrm{~Pa} \\
P_{\mathrm{H} 2} / P_{\mathrm{CO}} \approx 0.01\end{array}$ & -337 & 0.029 \\
\hline 2 & $\mathrm{Al}_{2} \mathrm{O}_{3}: \mathrm{Ti}$ & $\begin{array}{l}\mathrm{Al}_{2} \mathrm{O}_{3}+\mathrm{TiO}_{2}, \text { Thermal } \\
\text { treatment in } \mathrm{Ar}+\mathrm{CO} \\
+\mathrm{H}_{2}, P=1.3 \cdot 10^{5} \mathrm{~Pa}, \\
P_{\mathrm{CO}}+P_{\mathrm{H} 2} \sim 400 \mathrm{P}, \\
P_{\mathrm{H} 2} / P_{\mathrm{CO}} \approx 0.01\end{array}$ & $\begin{array}{c}P_{\mathrm{CO}}+P_{\mathrm{H} 2} \approx 7 \mathrm{~Pa} \\
P_{\mathrm{H} 2} / P_{\mathrm{CO}} \approx 0.01\end{array}$ & -337 & 0.02 \\
\hline 3 & $\mathrm{Al}_{2} \mathrm{O}_{3}: \mathrm{Ti}$ & $\mathrm{Al}_{2} \mathrm{O}_{3}: \mathrm{TiO}_{2}$ & $\begin{array}{c}\mathrm{Ar}+\mathrm{CO}+\mathrm{H}_{2} \\
P=1.3 \mathrm{~Pa} \\
P_{\mathrm{CO}}+P_{\mathrm{H} 2} \sim 400 \mathrm{~Pa} \\
P_{\mathrm{H} 2} / P_{\mathrm{CO}} \approx 0.01\end{array}$ & -399 & 0.009 \\
\hline 4 & $\mathrm{Al}_{2} \mathrm{O}_{3}: \mathrm{Ti}: \mathrm{C}$ & $\underset{(1 \mathrm{wt} \%)}{\mathrm{Al}_{2} \mathrm{O}_{3}+\mathrm{TiO}_{2}}+\mathrm{C}$ & $\begin{array}{c}P_{\mathrm{CO}}+P_{\mathrm{H} 2} \sim 7 \mathrm{~Pa} \\
P_{\mathrm{H} 2} / P_{\mathrm{CO}} \approx 0.01\end{array}$ & -337 & 0.001 \\
\hline
\end{tabular}

sponding to $K_{\max }$; $f$, the oscillator strength (equal to $=0.5$ as in [19]). The spectral band of $\mathrm{Ti}^{4+}$ ions in the region of $190-310 \mathrm{~nm}$ containing overlapping bands of different defects such as $F^{+}$-centers (the bands with maxima at 230 and $260 \mathrm{~nm}$ ), was singled out by the Alentsev-Fock method with subsequent resolution into elementary Gaussian components (for details see [20]). The criterion of resolution accuracy was the relation [21]

$$
\gamma=\frac{\sum_{i=0}^{m}\left(K_{i}^{\exp }-K_{i}^{c a l c}\right)^{2}}{\sum_{i=0}^{m}\left(K_{i}^{\exp }\right)^{2}} \leq 0.05
$$

where $m$ - are the points of the curve $K(\lambda)$, $K_{i}^{\text {exp }}$, the experimental values; $K_{i}^{c a l c}$, the values calculated from the sum of $K(\lambda)$ components at the corresponding wavelength. The calculation was made for $190-310 \mathrm{~nm}$ range, $m=120$. For the spectra presented in Fig. $4, \gamma$ amounts to $2-4 \cdot 10^{-3}$.

The concentration of $\mathrm{Ti}^{3+}$ was estimated using the empiric relation [22]:

$$
\left[\mathrm{Ti}^{3+}\right]=\frac{K_{514}}{18.55 \mathrm{~cm}^{-1}}, \quad w t \%,
$$

where $K_{514}$ is the coefficient of optical absorption at $514 \mathrm{~nm}$ wavelength.
Table 2 contains the data for the crystals which optical absorption spectra are presented in Fig. 5(b,c), as well as the data obtained for $\mathrm{Al}_{2} \mathrm{O}_{3}$ :Ti crystal grown from the raw material preliminarily reduced by thermal treatment in $\mathrm{Ar}+\mathrm{CO}+\mathrm{H}_{2}$ atmosphere during 20 hours at $2000 \mathrm{~K}$.

As seen while analyzing these data, the said preliminary thermal treatment of the raw material makes it possible to decrease the relative content of $\mathrm{Ti}^{4+}$ approximately by 1.5 times, that qualitatively coincides with the estimation which follows from Fig. 1. Diminution of the oxygen potential at the growth of the crystal in $\mathrm{Ar}+\mathrm{CO}+\mathrm{H}_{2}$ atmosphere and introduction of carbon into the raw material lead to practically equivalent result and allow to diminish the value of $\left[\mathrm{Ti}^{4+}\right] /\left[\mathrm{Ti}^{3+}\right]$ more than by $2-3$ times. As seen from the optical absorption spectra (Fig. 5), such a decrease of the content of $\mathrm{Ti}^{4+}$ ions leads to the corresponding diminution of the absorption (by 2-3 times) in the region of $800 \mathrm{~nm}$ that is bound up with the activator complexes $\mathrm{Ti}^{3+}-\mathrm{Ti}^{4+}$.

\section{Conclussions}

Thus, the presence of the additional inner reduction source (the introduction of $\mathrm{C}$ or $\mathrm{Al}_{4} \mathrm{C}_{3}$ ) during carbothermal treatment of the raw material makes it possible to effectively diminish the value of oxygen potential which defines the relative content of the activator in the charge state $\mathrm{Ti}^{4+}$ and $\mathrm{Ti}^{3+}-\mathrm{Ti}^{4+}$. 


\section{References}

1. P.F.Moulton, J.Opt.Soc.Am.B., 3, 125 (1986).

2. A.J.Strauss, R.E.Fahey, A.Sanchez, R.L.Aggarwal, SPIE Laser Nonlin. Opt. Mater., 681, 62 (1986).

3. A.Sanchez, A.J.Strauss, R.L.Aggarwal, R.E.Fahey, IEEE J.Quant.Electron., 24, 995 (1988).

4. R.L.Aggarval, A.Sanchez et al., IEEE J. Quant.Electron., 24, 1003 (1988).

5. N.S.Sidelnikova, S.V.Nizhankovskyi, V.V.Baranov, Functional Materials, 22, 461 (2015).

6. A.Ya.Danko, V.M.Puzikov, V.P.Seminozhenko, N.S.Sidelnikova, Technological Bases of Growth of Leucosapphire in Reducing Conditions. ISMA, Kharkov (2009) [in Russian].

7. $\mathrm{Hu} \mathrm{Ke}-Y a n, \mathrm{Xu}$ Jun, Wang Chuan-Yong et al., J. Inorg. Mater., 27, 1321 (2012).

8. S.V.Nizhankovskiy, A.Ya Dan'Ko, E.V. Krivonosov, V.M.Puzikov, J. Inorg. Mater., 46, 41 (2010).

9. L.V.Gurvich, I.V.Weitz, V.A.Medvedev et al., Thermodynamic Properties of Individual Substances. Reference Edition in 4 Volumes., V1, B2. Science, Moscow (1978) [in Russian].

10. L.V.Gurvich, I.V.Weitz, V.A.Medvedev et al., Thermodynamic Properties of Individual Substances. Reference Edition in 4 Volumes., V4, B2, Science, Moscow (1978) [in Russian].
11. M.Cancarevic, M.Zinkevich, F.Aldinger, Computer Coupling of Phase Diagrams and Thermochemistry, 31, 330 (2007).

12. A.Ya.Danko, N.S.Sidelnikova, Functional Materials, 8, 271 (2001).

13. L.V.Gurvich, I.V.Weitz, V.A.Medvedev et al., Thermodynamic Properties of Individual Substances. Reference Edition in 4 Volumes, V2, B2, Science, Moscow (1978) [in Russian].

14. L.V.Gurvich, I.V.Weitz, V.A.Medvedev et al., Thermodynamic Properties of Individual Substances. Reference Edition in 4 Vol., V3, B2, Science, Moscow (1981) [in Russian].

15. J.-M.Lihrmann, J.Tirlocq, P.Descamps, F.Cambier, J. Eur. Ceramic Soc., 19, 2781 (1999).

16. M.S.Akselrod, V.S.Kortov, D.J.Kravetsky, V.I.Gotlib, Radiat. Prot. Dosim., 32, 15 (1990).

17. X.Yang, H.Li, Y.Cheng et al., J.Cryst. Growth, 310, 3800 (2008).

18. X.Yang, J.Li, Q.Y.Bi et al., J.Appl.Phys., 104, 1 (2008).

19. N.A.Moskvin, V.A.Sandulenko, E.A.Sidorova, J. Appli. Spectrosc., 32, 1017 (1980).

20. S.V.Nizhankovskii, N.S.Sidel'nikova, V.V.Baranov, Phys. Solid State. 57, 763 (2015).

21. V.G.Tyazhelova, J. Appl. Spectr., 10, 22 (1969).

22. J.Stone-Sundberg, M.Kokta, A.Silberstein et al., Workshop: Technological Bottlenecks in CHISP Lasers, Paris, April 1-4, (2003). 